\title{
OPTIMALISASI PENINGKATAN KETERAMPILAN MENGAJAR MAHASISWA DENGAN MENERAPKAN MODEL BERBASIS MASALAH DALAM PEMBELAJARAN IPS DI SD
}

\author{
Nina Sundari ${ }^{1}$ \\ Susilowati ${ }^{2}$ \\ Yona Wahyuningsih 3
}

\begin{abstract}
ABSTRAK
Penelitian ini dilatarbelakangi bahwa keterampilan mengajar mahasiswa dalam pembelajaran IPS yang disimulasikan di dalam kelas belum terlihat selayaknya seorang guru dengan menampilkan berbagai keterampilan mengajar yang meliputi membuka menutup pelajaran, menjelaskan, bertanya dasar dan lanjut, mengelola gelas, mengadakan variasi, membimbing diskusi dan kelompok kecil. Dari temuan tersebut dapat dirumuskan masalah yakni bagaimana peningkatkan keterampilan mengajar mahasiswa dalam pembelajaran IPS dengan menggunakan model berbasis masalah. Penelitian ini pun bertujuan meningkatkan keterampilan mengajar mahasiswa dalam pembelajaran IPS dengan menggunakan model berbasis masalah. Pelaksanaan pembelajaran berbasis masalah dilakukan oleh mahasiswa semester 4 di UPI Kampus Cibiru menggunakan metode deskriptif yang diawali dengan penyajian permasalahan diikuti dengan melakukan analisa terhadap informasi sebagai landasan dalam memecahkan permasalahan. Teknik pengumpulan data menggunakan observasi, catatan lapangan penampilan mengajar mahasiswa pada tiap pertemuan perkuliahan. Hasil penelitian mengalami peningkatan yakni pada Pembelajaran 1 mahasiswa mampu mengoptimalkan 4 keterampilan mengajar, Pembelajaran 2 mahasiswa mampu mengoptimalkan 5 keterampilan mengajar, dan Pembelajaran 3 keterampilan mengajar dilakukan optimal. Hal ini berdasarkan hasil observasi dan hasil penampilan simulasi mahasiswa.

Kata Kunci: Keterampilan Mengajar, Model Berbasis Masalah
\end{abstract}

\section{A. PENDAHULUAN}

Pribadi yang telah mengalami proses pendidikan akan menunjukkan perbedaan kualitasnya, seperti intelegensi, interaksi sosial, dan kecakapan hidup. Negara Indonesia membutuhkan pribadi-pribadi yang berkualitas. Melalui Pendidikan IPSlah sebagai wahana mengembangkan semua potensi yang dimiliki. Figur profesional sejak dini diupayakan untuk calon pendidik seperti bagaimana keterampilan mengajar yang harus dikuasai seoptimal mungkin. Keterampilan adalah pola kegiatan yang bertujuan, yang memerlukan manipulasi dan koordinasi informasi yang dipelajari. Mengajar adalah membimbing suatu kegiatan siswa dalam proses belajar, yang merupakan pengaturan dan mengorganisasi lingkungan yang ada di sekitar siswa sehingga dapat mendorong

\footnotetext{
1 Dosen UPI Kampus Cibiru

2 Dosen UPI Kampus Cibiru

${ }^{3}$ Dosen UPI Kampus Cibiru
} 
dan menumbuhkan siswa melakukan kegiatan belajar dengan baik. Keterampilan mengajar meliputi membuka menutup pelajaran, menjelaskan, bertanya dasar dan lanjut, mengelola gelas, mengadakan variasi, membimbing diskusi dan kelompok kecil menjadi pelatihan dan pembiasaan calon pendidik sebagai bekal ketika berada di lapangan. Oleh karena itu keterampilan mengajar ini harus di latih dan di kembangkan, sehingga para calon guru atau guru dapat memiliki banyak pilihan untuk dapat melayani siswa dalam melakukan proses pembelajaran.

Pengoptimalan keterampilan mengajar ini menjadi pokok penelitian khususnya yang terjadi pada mahasiswa UPI Kampus Cibiru mata kuliah Pendidikan IPS SD. Pembelajaran IPS perlu dikemas dimulai dari merancang kegiatan pembelajaran hingga pelaksanaannya. Berdasarkan latar belakang masalah tersebut, rumusan pertanyaan penelitian yakni "Bagaimana keterampilan mengajar mahasiswa menggunakan model berbasis masalah pada pendidikan IPS di SD?". Adapun tujuan penelitian ini untuk mengidentifikasi keterampilan mengajar mahasiswa dengan menerapkan model berbasis masalah pada pembelajaran IPS di SD.

\section{B. TIJAUAN PUSTAKA}

\section{Model Pembelajaran Berbasis Masalah}

Pembelajaran Berbasis Masalah adalah pendekatan pembelajaran yang menggunakan masalah sebagai langkah awal untuk mendapatkan pengetahuan baru. Seperti yang diungkapkan oleh Suyatno (2007, hlm.58) bahwa "Model Pembelajaran Berbasis Masalah adalah proses pembelajaran yang titik awal pembelajaran dimulai berdasarkan masalah dalam kehidupan nyata siswa dirangsang untuk mempelajari masalah berdasarkan pengetahuan dan pengalaman telah mereka miliki sebelumnya (prior knowledge) untuk membentuk pengetahuan dan pengalaman baru". Jadi, pembelajaran ini menggunakan masalah sebagai langkah awal dalam mengumpulkan dan mengintregasikan pengetahuan baru.

Arends (dalam Trianto, 2007, hlm.68) menyatakan bahwa:

“Pembelajaran Berbasis Masalah merupakan suatu pendekatan pembelajaran di mana siswa mengerjakan permasalahan yang autentik dengan maksud untuk menyusun pengetahuan mereka sendiri, mengembangkan inkuiri dan keterampilan berpikir tingkat lebih tinggi, mengembangkan kemandirian dan percaya diri".

Dari pemaparan kedua ahli, dapat disimpulkan bahwa Pembelajaran Berbasis Masalah merupakan model pembelajaran yang mengacu pada permasalahan yang berada di lingkungan masyarakat dikaitkan dengan pengalaman yang sudah dimiliki sebelumnya dengan memberikan rangsangan/arahan agar siswa dapat berpikir kritis.

Berbagai pengembang menyatakan bahwa ciri utama Model Pembelajaran Berbasis Masalah ini dalam Trianto (2007, hlm.68) adalah :

1) Pengajuan pertanyaan atau masalah.

2) Berfokus pada keterkaitan antar disiplin.

3) Penyelidikan autentik.

4) Menghasilkan produk atau karya.

5) Kolaborasi. 
Pembelajaran Model Pembelajaran Berbasis Masalah tidak dirancang untuk membantu guru memberikan informasi sebanyak-banyaknya kepada siswa. Menurut Arends (2008, hlm.70) bahwa :

"Model Pembelajaran Berbasis Masalah bertujuan untuk membantu siswa mengembangkan keterampilan berfikir dan keterampilan pemecahan masalah, belajar peranan orang dewasa secara autentik, memungkinkan siswa untuk mendapatkan rasa percaya diri atas kemampuan yang dimilikinya sendiri, untuk berfikir dan menjadi pelajar yang mandiri".

Pada Model Pembelajaran Berbasis Masalah terdapat lima tahap utama yang dimulai dengan memperkenalkan siswa terhadap masalah yang diakhiri dengan tahap penyajian dan analisis hasil kerja siswa. Kelima tahapan tersebut menurut pendapat Arends (2008, hlm.57) dapat dijabarkan sebagai berikut.

Fase 1 Memberikan orientasi tentang permasalahannya kepada siswa, tahap awal ini sikap guru harus mengkomunikasikan jelas maksud dan tujuan dari pemeblajaran yang akan dilakasanakan lalu guru memberikan sebuah pertanyaan yang berisikan tentang suatu permasalahan yang ada di lingkungan siswa. Sikap ini harus dibarengi dengan sikap positif yang jelas sehingga tidak membuat kebingungan siswa.

Fase 2 Mengorganisasikan siswa untuk meneliti, tahap ini guru harus mampu mengoorganisasikan siswa ke dalam tim-tim berbasis masalah dan membantu mereka dalam menginvestigasi permasalahan yang didapatnya.

Fase 3 Membantu investigasi mandiri dan kelompok, tahap ini guru mendorong siswa mengumpulkan data dan melaksanakan eksperimen mental atau aktual sampai mereka paham mengenai situasi masalah yang ada.

Fase 4 Mengembangkan dan mempresentasikan artefak dan exhibit, tahap ini guru membantu siswa dalam merencanakan dan menyiapkan karya yang sesuai seperti laporan, video, model dan membantu mereka untuk berbagai tugas dengan kelompoknya.

Fase 5 Menganalisa dan mengevaluasi proses mengatasi masalah, tahap ini membantu siswa menganalisis dan mengevaluasi proses berpikirnya sendiri maupun keterampilan investigatif dan keterampilan intelektual yang mereka guanakan.

Sanjaya (2005, hlm.220-221) menyatakan Model Pembelajaran Berbasis Masalah mempunyai beberapa kelebihan dan kelemahan dalam pelaksanaannya. Kelebihan Model Pembelajaran Berbasis Masalah lainnya adalah:

1) Menantang kemampuan siswa serta memberikan kepuasan untuk menemukan pengetahuan baru bagi siswa

2) Meningkatkan aktifitas pembelajaran siswa

3) Membantu siswa bagaimana mentransfer pengetahuan mereka untuk memahami masalah dalam kehidupan nyata

4) Membantu siswa untuk mengembangkan pengetahuan barunya dan bertanggung jawab dalam pembelajaran yang mereka lakukan.

5) Mengembangkan kemampuan siswa untuk berpikir kritis 
Adapun kelemahan dari pembelajaran berbasis masalah yaitu:

1. Manakala siswa tidak memiliki minat atau tidak mempunyai kepercayaan bahwa masalah yang dipelajari sulit untuk dipecahkan, maka mereka akan merasa enggan untuk mencoba.

2. Keberhasilan strategi pembelajaran ini membutuhkan waktu yang cukup laa untuk persiapan.

3. Tanpa pemahaman mengapa mereka berusaha untuk memecahkan masalah yang sedang dipelajari, maka mereka tidak akan belajar apa yang mereka ingin pelajari.

\section{Keterampilan Mengajar}

Keterampilan mengajar adalah kecakapan atau kemampuan guru dalam menyajikan materi pelajaran antara lain, menguasai bahan pengajaran mampu memilih metode yang tepat dan penguasaan kelas yang baik. Asril (2010, hlm.5) memaparkan delapan keterampilan dasar mengajar adalah sebagai berikut :

a. Keterampilan Menjelaskan

Keterampilan menjelaskan merupakan aspek yang sangat penting bagi guru Penguasaan keterampilan menjelaskan yang didemonstrasikan guru akan memungkinkan siswa memiliki pemahaman yang mantap tentang masalah yang dijelaskan, serta meningkatnya keterlibatan siswa dalam kegiatan pembelajaran.

\section{b. Keterampilan Bertanya}

Keterampilan bertanya merupakan ucapan atau pertanyaan yang dilontarkan guru yang menuntun respon atau jawaban dari peserta didik. Keterampilan bertanya merupakan bagian yang tidak terpisahkan dalam rangka meningkatkan kualitas proses dan hasil pembelajaran, yang sekaligus merupakan bagian dari keberhasilan dalam pengelolaan instruksional dan pengelolaan kelas. Melalui keterampilan bertanya guru mampu mendeteksi hambatan proses berpikir di kalangan siswa dan sekaligus dapat memperbaiki dan meningkatkan proses belajar di kalangan siswa.

\section{c. Keterampilan Menggunakan Variasi}

Pengertian penggunaan variasi merupakan keterampilan guru dalam menggunakan bermacam kemampuan untuk mewujudkan tujuan belajar peserta didik sekaligus mengatasi kebosanan dan menimbulkan minat, gairah dan aktivitas belajar mengajar yang efektif. Variasi hendaknya digunakan dengan suatu maksud tertentu yang relevan dengan tujuan yang hendak dicapai. Dalam menggunakan keterampilan variasi sebaiknya semua jenis variasi digunakan. Disamping itu juga harus ada variasi penggunaan komponen untuk tiap jenis variasi, terutama penggunaan variasi gaya mengajar, dalam bervariasi harus disesuaikan dengan materi pelajaran yang akan disampaikan agar menarik siswa untuk memperhatikan atau mendengarkan penjelasan guru. Variasi harus digunakan secara lancar, berkesinambungan dan direncanakan secara baik dan eksplisit dicantumkan dalam rencana pelajaran, sehingga tidak akan merusak perhatian siswa dan tidak menganggu proses belajar mengajar. 


\section{d. Keterampilan Memberi Penguatan}

Memberi penguatan atau reincorcement merupakan tindakan atau respon terhadap suatu bentuk perilaku yang dapat mendorong munculnya peningkatan kualitas tingkah laku tersebut di saat yang lain.Melalui keterampilan penguatan (reinforcement) yang diberikan guru, maka siswa akan merasa terdorong selamanya untuk meberikan respon setiap kali muncul stimulus dari guru, atau siswa akan berusaha menghindari respon yang dianggap tidak bermanfaat. Penguatan juga berguna untuk mendorong siswa memperbaiki tingkah lakunya dan meningkatkan kerjanya.

\section{e. Keterampilan Membuka dan Menutup Pelajaran}

Keterampilan membuka pelajaran adalah usaha guru untuk mengkondisikan mental peserta didik agar siap dalam menerima pelajaran. Dalam membuka pelajaran peserta didik harus mengetahui tujuan yang akan dicapai dan langkahlangkah yang akan ditempuh. Keterampilan menutup pelajaran adalah keterampilan guru dalam mengakhiri kegitan inti pelajaran. Dalam menutup pelajaran, guru dapat menyimpulkan materi pelajaran, mengetahui tingkat pencapaian peserta didik dan tingkat keberhasilan guna dalam proses belajar mengajar. Pada dasarnya keterampilan membuka dan menutup pelajaran adalah keterampilan yang berkaitan dengan kegiatan atau usaha yang dilakukan oleh seorang guru dalam memulai dan mengakhiri suatu pelajaran.

\section{f. Keterampilan Mengajar Kelompok Kecil dan Perseorangan}

Keterampilan mengajar kelompok kecil adalah kemampuan guru melayani kegiatan peserta didik dalam belajar secara kelompok dengan jumlah peserta didik berkisar antara 3 hingga 5 orang atau paling banyak 8 orang untuk setiap kelompoknya. Sedangkan keterampilan dalam pengajaran perorangan atau pengajaran individual adalah kemampuan guru dalam menentukan tujuan, bahan ajar, prosedur dan waktu yang digunakan dalam pengajaran dengan memperhatikan tuntutan-tuntutan atau perbedaan-perbedaan individual peserta didik.

\section{g. Keterampilan Mengelola Kelas}

Keterampilan mengelola kelas merupakan kemampuan guru dalam mewujudkan dan mempertahankan suasana belajar mengajar yang optimal. Tujuan dari pengelolaan kelas adalah Mewujudkan situasi dan kondisi kelas yang memungkinkan peserta didik mengembangkan kemampuannya secara optimal, Mengatur semua perlengkapan dan peralatan yang memungkinkan peserta didik belajar sesuai dengan lingkungan sosial, emosional dan intelektual

h. Keterampilan membimbing Diskusi Kelompok kecil

Diskusi kelompok kecil adalah suatu proses belajar yang dilakukan dalam kerja sama kelompok bertujuan memecahkan suatu permasalahan, mengkaji konsep, prinsip atau kelompok tertentu. 


\section{METODE PENELITIAN}

Penelitian akan dilaksanakan di UPI Kampus Cibiru kepada mahasiswa PGSD konsentrasi IPS dalam membelajarkan IPS di SD. Penelitian akan dilaksanakan selama lima bulan dari bulan September hingga awal bulan Januari 2014. Ditinjau dari jenis datanya pendekatan penelitian yang digunakan dalam penelitian ini adalah pendekatan kualitatif metode deskriptif. Penelitian deskriptif yaitu penelitian yang berusaha untuk menuturkan pemecahan masalah yang ada sekarang berdasarkan data-data.

Instrumen yang digunakan dalam penelitian yaitu IPKG 1 dan 2 (Instrumen Penilaian Kinerja Guru), dan lembar observasi. Instrumen ini digunakan untuk mengungkap akivitas dan keterampilan khusus mahasiswa ketika melaksanakan simulasi dalam pembelajaran IPS di SD serta interaksi yang terjadi antara mahasiswa dan siswa SD dalam pembelajaran dari awal hingga akhir pembelajaran. Analisis data diarahkan untuk mencari dan menemukan upaya yang dilakukan guru dalam meningkatkan kualitas proses belajar siswa. Data kualitatif dianalisis dengan cara dikumpulkan dan diklasifikasikan untuk ditafsirkan agar data tersebut mempunyai makna.

\section{HASIL PENELITIAN}

Penelitian ini dilakukan secara alamiah, tanpa menginformasikan terlebih dahulu agar peneliti dapat menemukan banyak hal yang penting dan menarik dari pembelajaran tersebut. Hasil penelitian diawali dengan perencanaan yakni peneliti sebagai dosen mata kuliah Pendidikan IPS di SD semester 4. Pertemuan pertama mata kuliah ini, disampaikan tujuan dan silabus mata kuliah yang akan dilaksanakan sampai semester usai. Penyampaian prosedur perkuliahan seperti absensi, tugas, ujian yang akan dilaksanakan selama perkuliahn. Setelah disepakati oleh mahasiswa, peneliti melakukan diskusi berupa presentasi dengan membentuk kelompok-kelompok kecil mahasiswa sesuai dengan topik perkuliahan. Perkuliahan dilaksanakan sebanyak 16 pertemuan termasuk ujian tengah semester dan ujian akhir semester, 14 pertemuan yang terdiri dari topik perkuliahan dibagi secara merata pada kelompok, sehingga tiap kelompok mendapatkan satu topik yang akan dipresentasikan dan ditampilkan simulasi pembelajaran berdasarkan penelitian yang disusun yaitu pembelajaran berbasis masalah pada pembelajaran IPS di SD. Kesepakatan kelompok terdiri dari kelas rendah dan kelas tinggi, tiap kelompok mempunyai topik simulasi yang berbeda seperti perkembangan teknologi, jenis-jenis pekerjaan, permasalahan sosial, keanekaragaman sosial dan sebagainya.

Topik yang akan dipresentasikan tiap kelompok disepakati terlebih dahulu dengan melakukan undian yaitu pengocokan nomor pada tiap-tiap kelompok untuk melakukan presentasi dan simulasi pada pertemuan perkuliahan yang akan datang. Penomoran 1-14 dikumpulkan pada satu orang mahasiswa dan perwakilan mahasiswa mengambil satu gulungan kertas yang telah dikumpulkan sebelumnya yang berisikan nomor dan topik yang akan dipresentasikan dan disimulasikan pada pertemuan yang akan datang. Seterusnya tiap kelompok sudah mendapatkan nomor yang telah disepakati bersama maka kelompok yang pertama tampil akan mulai berdiskusi bersama kelompoknya mengenai pembahasan topik yang akan 
dipresentasikan dan disimulasikan itu. Semua kelompok diwajibkan tampil sesuai dengan topik yang didapatnya. Pada pertengahan pertemuan yaitu pertemuan ke-8 akan dilaksanakan Ujian Tengah Semester (UTS) jadi mahasiswa tidak melaksanakan presentasi dan simulasi.

Tata cara pelaksanaan presentasi yaitu kelompok yang melaksanakan presentasi menyajikan di depan kelas dengan segala persiapan yakni makalah, resume dan slide untuk ditampilkan di depan kelas sehingga kelompok yang tidak tampil dapat menyimak segala aktivitas kegiatan presentasi dan diskusi dengan baik. Hal ini perlu adanya partisipasi dari kelompok lainnya berupa penambahan materi, kritik, dan saran serta pertanyaan yang dijadikan diskusi berdasarkan topik yang dibahas. Setelah selesai presentasi, diakhiri dengan simulasi yang menjadi bagian dari penelitian yaitu perwakilan kelompok melakukan simulasi berdasarkan topik yang diambil atas kesepakatan kelompoknya.

Kegiatan penelitian berupa simulasi mengajar yang dilakukan mahasiswa semester 4 menggunakan model berbasis masalah tiap Pembelajarannya

\section{Pembelajaran 1}

Presentasi perkuliahan dilakukan oleh kelompok 9 dengan materi "Pembelajaran Kontruktivis". Seperti biasa mahasiswa melakukan diskusi kelompok dan berbagai partisipasi dilakukan di dalam kelas dengan pengarahan dan bimbingann dosen untuk memperkuat hasil diskusi dan komentar yang ditanggapi. Setelah selesai dilanjutkan simulasi yang dilakukan untuk mengetahui keterampilan mengajar mahasiswa.

Rencana pembelajaran yang dilakukan yaitu mengenai "Teknologi Produksi" materi kelas IV semester 2 yang disimulasikan oleh Ina Agustina (perwakilan akan kocokan yang keluar untuk melaksanakan simulasi yang sebelumnya sudah melakukan kesepakatan terlebih dahulu sehingga peralatan dan perlengkapan simulasi sudah tersedia dengan baik.

Kegiatan simulasi yang dilakukan terdapat tiga tahap yakni kegiatan awal, kegiatan inti, dan kegiatan akhir. Berdasarkan hasil observasi dan temuan yang terjadimasih rendahnya keterampilan mengajar mahasiswa menggunakan model berbasis masalah pada Pembelajaran pertama. Dapat dilihat pada tabel berikut di bawah ini.

Tabel 1

Temuan Lapangan Pembelajaran 1

\begin{tabular}{|l|l|}
\hline $\begin{array}{l}\text { Keterampilan } \\
\text { Mengajar }\end{array}$ & Temuan \\
\hline $\begin{array}{l}\text { Membuka dan } \\
\text { Menutup Pelajaran }\end{array}$ & $\begin{array}{l}\text { Melakukan apersepsi dengan menyanyikan "Anak Gembala" } \\
\text { bersama. Akan tetapi ketika penyimpulan pembelajaran tidak } \\
\text { adanya tindak lanjut yang diberikan sehingga pemerolehan } \\
\text { materi berupa yang dipaparkan saja tanpa ada pengulangan } \\
\text { untuk menyimpan kembali informasi yang diterima. }\end{array}$ \\
\hline $\begin{array}{l}\text { Bertanya Dasar dan } \\
\text { Lanjut }\end{array}$ & $\begin{array}{l}\text { Masih memberikan pertanyaan yang mengundang jawaban } \\
\text { serempak tanpa ada pertanyaan lanjut, melainkan simulator tidak } \\
\text { memberikan kesempatan bertanya. }\end{array}$ \\
\hline
\end{tabular}




\begin{tabular}{|l|l|}
\hline Menjelaskan & $\begin{array}{l}\text { Penyampaian materi sudah dijelaskan namun kurang hirarki/ } \\
\text { tidak terorganisasi dengan baik }\end{array}$ \\
\hline MengadakanVariasi & $\begin{array}{l}\text { Sudah mampu melakukan perjanjian di kelas berupa sanksi } \\
\text { apabila terjadi kebisingan di dalam kelas dan membuat media } \\
\text { gambar terlihat dengan jelas }\end{array}$ \\
\hline Mengelola Kelas & $\begin{array}{l}\text { Melakukan perubahan posisi tempat duduk ketika diskusi } \\
\text { kelompok }\end{array}$ \\
\hline $\begin{array}{l}\text { Membimbing Diskusi } \\
\text { Kelompok Kecil }\end{array}$ & $\begin{array}{l}\text { Simulator melakukan bimbingan pada tiap kelompok yang } \\
\text { berdiskusi ketika lembar kerja yang sudah diberikan pada setiap } \\
\text { kelompok. }\end{array}$ \\
\hline $\begin{array}{l}\text { Mengajar Kelompok } \\
\text { Kecil dan Perorangan }\end{array}$ & $\begin{array}{l}\text { Ketika diskusi kelompok, simulator menjelaskan kembali } \\
\text { petunjuk kerja yang akan dilakukan pada setiap kelompok yang } \\
\text { bertanya karena mengalami kesulitan ketika menjawab soal }\end{array}$ \\
\hline $\begin{array}{l}\text { Memberikan } \\
\text { Penguatan }\end{array}$ & $\begin{array}{l}\text { Memberikan penguatan berupa tepuk tangan dan mengucapkan } \\
\text { kata "Bagus" pada perwakilan dan setiap yang berani } \\
\text { mengemukakan jawabannya. }\end{array}$ \\
\hline
\end{tabular}

\section{Pembelajaran 2}

Presentasi perkuliahan dilakukan oleh kelompok 10 dengan materi "Pengertian, tujuan dan prinsip Pengukuran, Penilaian dan Evaluasidalam Pembelajaran IPS SD". Seperti biasa mahasiswa melakukan diskusi kelompok dan berbagai partisipasi dilakukan di dalam kelas dengan pengarahan dan bimbingann dosen untuk memperkuat hasil diskusi dan komentar yang ditanggapi. Setelah selesai dilanjutkan simulasi yang dilakukan untuk mengetahui keterampilan mengajar mahasiswa.

Rencana pembelajaran yang dilakukan yaitu mengenai "Sumber Energi" materi kelas IV semester 1 dengan mengaitkan pembelajaran IPS, matematika dan IPA yang disimulasikan oleh Deni Kusmaya (perwakilan akan kocokan yang keluar untuk melaksanakan simulasi yang sebelumnya sudah melakukan kesepakatan terlebih dahulu sehingga peralatan dan perlengkapan simulasi sudah tersedia dengan baik.

Kegiatan simulasi yang dilakukan terdapat tiga tahap yakni kegiatan awal, kegiatan inti, dan kegiatan akhir. Berdasarkan hasil observasi dan temuan yang terjadi masih rendahnya keterampilan mengajar mahasiswa menggunakan model berbasis masalah pada Pembelajaran pertama. Dapat dilihat pada tabel berikut di bawah ini.

\section{Tabel 2}

Temuan Lapangan Pembelajaran 2

\begin{tabular}{|l|l|}
\hline Keterampilan Mengajar & Temuan \\
\hline $\begin{array}{l}\text { Membuka dan Menutup } \\
\text { Pelajaran }\end{array}$ & $\begin{array}{l}\text { Melakukan apersepsi dengan menyanyikan "Ibu Pertiwi" } \\
\text { bersama. Ketika kegiatan penyimpulan pembelajaran tindak } \\
\text { lanjut diberikan sehingga pemerolehan materi berupa yang } \\
\text { dipaparkan saja tanpa ada pengulangan untuk menyimpan } \\
\text { kembali informasi yang diterima. }\end{array}$ \\
\hline $\begin{array}{l}\text { Bertanya Dasar dan } \\
\text { Lanjut }\end{array}$ & $\begin{array}{l}\text { Masih memberikan pertanyaan yang mengundang jawaban } \\
\text { serempak tanpa ada pertanyaan lanjut, melainkan simulator }\end{array}$ \\
\hline
\end{tabular}




\begin{tabular}{|l|l|}
\hline & tidak memberikan kesempatan bertanya. \\
\hline Menjelaskan & $\begin{array}{l}\text { Penyampaian materi sudah hirarki/ terorganisasi dengan baik } \\
\text { berupa runtut informasi tentang sumber daya yang ada di } \\
\text { Indonesia, macam-macam energi yang dihasilkan hingga } \\
\text { bagaimana mengelola sumber energi bagi kehidupan } \\
\text { masyarakat. }\end{array}$ \\
\hline Mengadakan Variasi & $\begin{array}{l}\text { Sudah mampu melakukan perjanjian di kelas berupa sanksi } \\
\text { apabila terjadi kebisingan di dalam kelas dan membuat media } \\
\text { gambar terlihat dengan jelas }\end{array}$ \\
\hline $\begin{array}{l}\text { Membelola Kelas } \\
\text { Kelompok Kecil }\end{array}$ & $\begin{array}{l}\text { Melakukan perubahan posisi tempat duduk ketika diskusi } \\
\text { kelompok }\end{array}$ \\
\hline $\begin{array}{l}\text { Mengajar Kelompok Kecil } \\
\text { dan Perorangan }\end{array}$ & $\begin{array}{l}\text { Setimulator melakukan bimbingan pada tiap kelompok yang } \\
\text { berdiskusi ketika lembar kerja yang sudah diberikan pada } \\
\text { setiap kelompok. } \\
\text { petunjuk kerja yang akan dilakukan pada setiap kelompok yang } \\
\text { bertanya karena mengalami kesulitan ketika menjawab soal }\end{array}$ \\
\hline Memberikan Penguatan & $\begin{array}{l}\text { Memberikan penguatan berupa tepuk tangan dan } \\
\text { mengucapkan kata “Bagus" pada perwakilan dan setiap yang } \\
\text { berani mengemukakan jawabannya. }\end{array}$ \\
\hline
\end{tabular}

\section{Pembelajaran 3}

Presentasi perkuliahan dilakukan oleh kelompok 11 dengan materi "Jenis dan Teknik Pengukuran, Penilaian, dan Evalausi dalam Pembelajaran IPS SD". Seperti biasa mahasiswa melakukan diskusi kelompok dan berbagai partisipasi dilakukan di dalam kelas dengan pengarahan dan bimbingann dosen untuk memperkuat hasil diskusi dan komentar yang ditanggapi. Setelah selesai dilanjutkan simulasi yang dilakukan untuk mengetahui keterampilan mengajar mahasiswa.

Rencana pembelajaran yang dilakukan yaitu mengenai "Indahnya Negeriku" materi kelas IV semester 2 dengan mengaitkan pembelajaran IPS, Bahasa Indonesia dan PPKn yang disimulasikan oleh Desi Aprianti (perwakilan akan kocokan yang keluar untuk melaksanakan simulasi yang sebelumnya sudah melakukan kesepakatan terlebih dahulu sehingga peralatan dan perlengkapan simulasi sudah tersedia dengan baik.

Kegiatan simulasi yang dilakukan terdapat tiga tahap yakni kegiatan awal, kegiatan inti, dan kegiatan akhir. Berdasarkan hasil observasi dan temuan yang terjadi masih rendahnya keterampilan mengajar mahasiswa menggunakan model berbasis masalah pada Pembelajaran pertama. Dapat dilihat pada tabel berikut di bawah ini.

\section{Tabel 3}

Temuan Lapangan Pembelajaran 3

\begin{tabular}{|l|l|}
\hline Keterampilan Mengajar & Temuan \\
\hline Membuka dan Menutup & Melakukan apersepsi dengan menyanyikan “Dari Sabang \\
Pelajaran & Sampai Merauke bersama dengan menggunakan peta \\
& Indonesia agar lebih terarah. Ketika kegiatan penyimpulan \\
& pembelajaran tindak lanjut diberikan sehingga pemerolehan \\
& materi berupa yang dipaparkan saja tanpa ada pengulangan \\
\hline
\end{tabular}




\begin{tabular}{|l|l|}
\hline & $\begin{array}{l}\text { untuk menyimpan kembali informasi yang diterima berupa } \\
\text { rangkuman dari materi yang didapat. }\end{array}$ \\
\hline $\begin{array}{l}\text { Lertanya Dasar dan } \\
\text { Simulator memberikan kesempatan bertanya dengan } \\
\text { memancing pertanyaan dasar (sederhana berupa "tempat } \\
\text { wisata apa yang sudah kalian kunjungi di sekitar Bandung? } \\
\text { pertanyaan tersebut menjadi kesempatan jawaban yang } \\
\text { bervariasi hingga simulator memberikan pertanyaan lanjut } \\
\text { berupa "Mengapa kalian memilih tempat tersebut?". } \\
\text { pertanyaan terbuka ini yang menjadi bahan materi yang akan } \\
\text { dibahas pada pembelajaran. }\end{array}$ \\
\hline Menjelaskan & $\begin{array}{l}\text { Penyampaian materi secara jelas dan terorganisasi dilakukan } \\
\text { dengan penjabaran dari yang umum menuju yang khusus dari } \\
\text { Indonesia hingga daerah tempat tinggal }\end{array}$ \\
\hline Mengadakan Variasi & $\begin{array}{l}\text { Mengadakan berbagai variasi dari segi gaya bicara lantang dan } \\
\text { tegas serta penggunaan media peta dan gambar menjadi daya } \\
\text { tarik dalam pembelajaran }\end{array}$ \\
\hline Mengelola Kelas & $\begin{array}{l}\text { Melakukan perubahan posisi tempat duduk ketika diskusi } \\
\text { kelompok }\end{array}$ \\
\hline Membimbing Diskusi & $\begin{array}{l}\text { Simulator melakukan bimbingan pada tiap kelompok yang } \\
\text { berdiskusi ketika lembar kerja yang sudah diberikan pada } \\
\text { Ketiap kelompok. }\end{array}$ \\
\hline $\begin{array}{l}\text { Melompok Kecil } \\
\text { dan Perorangan }\end{array}$ & $\begin{array}{l}\text { Ketika diskusi kelompok, simulator menjelaskan kembali } \\
\text { petunjuk kerja yang akan dilakukan pada setiap kelompok yang } \\
\text { bertanya karena mengalami kesulitan ketika menjawab soal }\end{array}$ \\
\hline Memberikan Penguatan & $\begin{array}{l}\text { Memberikan penguatan berupa tepuk tangan dan } \\
\text { mengucapkan kata "Bagus" pada perwakilan dan setiap yang } \\
\text { berani mengemukakan jawabannya. }\end{array}$ \\
\hline
\end{tabular}

\section{E. KESIMPULAN DAN SARAN}

Berdasarkan hasil penelitian maka dapat disimpulkan bahwa keterampilan mengajar mahasiswa tiap pembelajarannya mengalami peningkatan. Berdasarkan hasil observasi dan temuan ketika pelaksanaan kegiatan simulasi yakni: Pembelajaran pertama hanya 4 keterampilan mengajar yang tercapai, pembelajaran kedua hanya 5 keterampilan mengajar dan pembelajaran ketiga keterampilan yang dilakukan mahasiswa sudah mencapai optimal yakni seluruh simulasi sudah mampu memperlihatkan kesiapan dalam bersimulasi.

Berdasarkan kesimpulan tersebut maka dapat disarankan:

a. Kepada mahasiswa, berlatih bersimulasi selayaknya pendidik yang profesional.

b. Bagi peneliti, selalu memfasilitasi mahasiswa dalam perkuliahan

c. Kepada lembaga UPI Kampus Cibiru, senantiasa memfasilitasi sarana dan prasarana seperti penyediaan ruang mikro teaching dan media belajar lainnya.

\section{DAFTAR PUSTAKA}

Arends, R.I (2007). Learning to Teach. Yogyakarta: Pustaka Pelajar.

Asril, Z. (2010). Micro Teaching Disertai dengan Pedoman Pengalaman Lapangan .Jakarta :

Rajawali Pers.

Nazir, M. (2005). Metode Penelitian. Bogor: Ghalia Indonesia. 
Sanjaya, Wina., (2005). Pembelajaran dalam Implementasi Kurikulum Berbasis Kompetensi, Penerbit Media Group, Jakarta.

Suyatno. (2007). Menjelajah Pembelajaran Inovatif. Surabaya: Masmedia Buana Pustaka.

Trianto. (2007). Model-model Pembelajaran Inovatif Berorientasi Konstruktivis. Jakarta: Prestasi Pustaka. 